\title{
PLATÓN SOBRE LA ANOMALÍA CÍVICA DEL FILÓSOFO
}

\section{PLATO ON THE PHILOSOPHER'S CIVIC ODDNESS}

\author{
JONATHAN LAVILLA DE LERA* \\ Universidad del País Vasco (UPV-EHU)
}

\begin{abstract}
RESUMEN: La filosofía es un producto histórico que se afianza definitivamente con Platón y Aristóteles. En tanto que constituye una novedad en el interior de la ciudadestado, no sólo es mirada con desconfianza desde sus albores, sino que también es objeto de severas críticas. Los que se dedican a la filosofía son tildados de anómalos, como lo muestran algunos textos clásicos. En el contexto de su pensamiento y de su propuesta práctica, Platón dio continuidad a la imagen alocada del filósofo. No obstante, el Académico lo hizo de un modo irónico, mostrando que su extravagancia no reside en una desviación real respecto al comportamiento que por naturaleza es más idóneo para el humano, sino todo lo contrario, a saber, fruto de la errada opinión del vulgo. Precisamente, uno de los quehaceres más apremiantes para Platón en sus diálogos, además de precisar cuál es la naturaleza de la filosofía, es el de elaborar una defensa de la filosofía, presentándola como el modus vivendi más sensato y apropiado por naturaleza.
\end{abstract}

Palabras Clave: Platón, Sócrates, Aristófanes, filosofía, astronomía, eros.

"Doctor en Filosofía por la Universidad de Barcelona. Obtuvo también en dicha universidad la Licenciatura en Filosofía, el Grado en Filología Clásica y el Máster en Filosofía y Estudios Clásicos. En la actualidad es profesor laboral interino en el Departamento de Filosofía de los Valores y Antropología Social de la Universidad del País Vasco, y miembro del grupo de investigación Eidos: Platonisme i Modernitat. Dirección postal: Departamento de Filosofía de los Valores y Antropología Social, Facultad de Educación, Filosofía y Antropología, Universidad del País Vasco, av. Tolosa 70, 20018, San Sebastián. Email: jonathan.lavilla@ehu.eus 
Aвstract: Philosophy is an historical product, which is definitively consolidated with Plato and Aristotle. As it constitutes a novelty within the polis, it is not just regarded with suspicion from its very beginning, but it is also the target of severe criticism. Those who devote themselves to philosophy are stigmatized as odd people, as many classical texts show. Regarding his thinking and his practical proposal, the Academic gave continuity to the image of the philosopher as a crazy person. However, he did so in an ironic way. He suggested that the philosopher's strangeness is not due to a real deviation from the behaviour that, by nature, is most suitable for humans, but the opposite, i.e. that it is caused by the wrong opinions of those who are not philosophers. In fact, apart from defining the nature of philosophy, one of the most urgent tasks that Plato has to deal with in his dialogues is making a defence of philosophy as the best way of life, depicting it as the most sensible and natural.

KeYwords: Plato, Socrates, Aristophanes, Philosophy, astronomy, eros

\section{Introducción: la filosofía como novedad en la polis griega}

Por más que sea habitual referirse a Tales de Mileto o a los filósofos jonios, a Jenófanes, Parménides o, en general, a los presocráticos como los precursores de la filosofía, lo cierto es que hasta pasado el siglo V. a.C. no existió una disciplina llamada "filosofía», cuyos campo de estudio, metodología y estatuto epistemológico estuviesen netamente definidos respecto a otros géneros literarios, como la poesía, la historia y la retórica, entre otros (cf. Bonazzi, 2010, 23). La filosofía, al menos en el sentido en que se la concibe actualmente en el ámbito académico, nace en buena medida gracias al trabajo de Platón y Aristóteles. Hasta entonces, sin duda, el debate intelectual existía y se practicaba de una manera amplia y sin restricciones disciplinares, ya fuese en verso o en prosa, como muestran las obras de Hesíodo, Heráclito, Gorgias, Heródoto y tantos otros. Platón y Aristóteles dan continuidad a dicho debate, ellos también desde una gran pluralidad temática, pero definiendo qué es la filosofía ${ }^{1}$ y qué estatuto tiene respecto a las demás formas de pensamiento, para utilizar dicho criterio en su manera de abordar las

\footnotetext{
${ }^{1}$ Cabe señalar que otros autores como Isócrates también designaron su actividad — que era diversa respecto a los autores mencionados - con el término "filosofía» (cf. A Demónico 3.4; 4.2; 40.5; Contra los sofistas 1.6; 11.2; 14.4; 18.4; 21.2; Busiris 22.7; Panegírico 6.4; 10.3; 47.1; 186.9; A Nicocles 35.3; 51.2 etc.), pero fue el modo en el que Platón y Aristóteles emplearon este término el que tuvo éxito y ha condicionado la manera de entender esta palabra en los siglos posteriores. Dicho esto, cabe reconocer que si las palabras de Heráclides Póntico reproducidas por Diógenes Laercio fueran ciertas (1.12), la influencia de Pitágoras de
} 
cuestiones tratadas. Así, puede afirmarse que buena parte del proyecto intelectual platónico plasmado en los Diálogos consiste en definir y legitimar la filosofía como disciplina y forma de vida diferenciadas (cf. Nightingale, 1995).

Puesto que sus contornos quedan definidos a partir del siglo V. a.C., la filosofía supone una novedad en la polis, es decir, algo insólito respecto a la tradición de la ciudad-estado griega. Por un lado, constituye una innovación en lo que atańe a la manera en la que despliega el pensamiento. Uno de los puntos de partida es que puede explicarse la realidad o, dicho de otro modo, que puede hacerse ciencia. Además, para ello, el método que se privilegia es el de la argumentación ${ }^{2}$ - la cual siempre es revisable_- buscando las causas inmediatas y últimas de los elementos constitutivos de la realidad ${ }^{3}$. Sin duda, la vía ontológica y epistemológica de la filosofía constituye en sí misma una novedad, pero no es la única. Por otro lado, la innovación también se manifiesta en lo que a la ética y a la política se refiere. La política y la ética platónicas están estrechamente vinculadas con la propuesta cognoscitiva del Académico, en tanto que el conocimiento es el criterio que debe imperar en la política y, por tanto, el modus vivendi de un filósofo debe ser tal que le permita alcanzar el mayor grado de conocimiento posible. Una vida dedicada al saber constituye en sí misma una novedad importante, sobre todo, teniendo en cuenta que dicha práctica no constituye propiamente ningún oficio, a diferencia de lo que pasa con el artesano, el maestro de retórica o el rapsoda, entre otros. La filosofía no es una ocupación que pueda realizarse a tiempo parcial y como medio de vida; más bien, constituye una manera de situarse en el mundo, que hace estallar la dicotomía ocio/negocio ${ }^{4}$, lo cual, en sí mismo, resulta en cierta medida paradójico.

\footnotetext{
Samos resultó especialmente decisiva para el modo en que emplearon el término el Académico y el Peripatético (cf. Diogenes Laercio, Vidas y opiniones de los filósofos ilustres, 1.12.1-7).

2 Para un análisis de la vital relevancia que juega la argumentación en el engranaje Platónico, cf. Trabattoni, 2001.

3 Tal vez, alguno objete que los diálogos platónicos no están compuestos estrictamente por discursos argumentativos, puesto que otros recursos, entre ellos el mito, también desempeñan una labor destacada. Sin negar que el mito sea un recurso importante en la obra legada por Platón, pensamos que existen buenas y numerosas razones para defender que, en la filosofía platónica, la forma discursiva privilegiada es la argumentación, en consonancia con el perenne imperativo que parece perseguir a Sócrates, el cual lo impele a examinar sin descanso el valor de las opiniones propias y ajenas. Para un análisis del rol que desempeńa el mito en la filosofía platónica, cf. Trabattoni, 2012.

${ }^{4}$ A propósito del binomio $\sigma \chi 0 \lambda \eta \dot{\eta} / \alpha \sigma \chi 0 \lambda i ́ \alpha$, Ferrari ha sostenido acertadamente lo que sigue: "the philosopher's position cannot be satisfactorily mapped into the dichotomy between professional and lay, but is rather revealed through the inadequacy of any attempt at such mapping» (Ferrari, 1987, 21).
} 
A este respecto, la Academia constituye una piedra angular del proyecto platónico, en tanto que novedoso y exclusivo centro de formación de ciudadanos, el cual no sólo ofrece un nuevo modelo educativo de elevadas pretensiones epistemológicas y políticas para los jóvenes, sino que constituye una comunidad en la que poner en práctica una manera novedosa de desarrollar la vida en la ciudad y en la que el conocimiento se situaba en el centro. Hacer de la vida una búsqueda perpetua del conocimiento, y fundamentar la acción individual y política en función de los logros de dicha búsqueda, constituye la vía propuesta por Platón. Precisamente, esta actividad o modo de vida es lo que Platón bautizó con el término «filosofía».

\section{Voces críticas contra la incipiente filosofía}

Si bien la filosofía propiamente dicha nace con Platón y Aristóteles, lo cierto es que su actividad no florece de la nada, sino que es deudora de un proceso de ilustración que se remonta a tiempos anteriores. Los físicos jonios, la escuela eleática, los sofistas y el propio Sócrates, por nombrar sólo a algunos, inician el camino que más tarde será acotado con nitidez por los fundadores de la Academia y del Liceo. La actitud de todos ellos, ya sea por la manera de orientar sus investigaciones, por las técnicas empleadas para ello o por la temática tratada, chocan con la tradición heredada, esto es, con los relatos tradicionales y con la manera en la que justificar las decisiones políticas, escoger la voz autorizada y determinar el modo de vida apropiado.

La filosofía, ya desde su forma embrionaria, aparece como una actividad anómala, y por tanto inquietante, de la que muchos sectores de la ciudad desconfían. Tal vez, el ejemplo más paradigmático de la inquietud y sospecha con la que es percibida la actitud filosófica lo ofrezca el que fuera el maestro más insigne de Platón, a quien presumiblemente se debe que este último abandonase la carrera de poeta trágico para dedicarse a la filosofía (Cf. Diógenes Laercio, Vidas y opiniones de los filósofos ilustres, 3.5.5-3.6.1). Según lo referido por Platón en diálogos como Apología de Sócrates o Fedón y por Jenofonte en los diálogos Apología de Sócrates y Recuerdos de Sócrates, Sócrates no sólo fue juzgado públicamente por su peculiar actitud, sino que fue condenado a muerte ${ }^{5}$. En tanto que precursor

5 Para un estudio pormenorizado de las razones políticas que impulsaron estos hechos, cf. Solana Dueso, 2013. 
de un nuevo modo de vida y, si se quiere, de un nuevo método educativo, el ateniense fue acusado de impiedad y de corromper a los jóvenes de la ciudad. En efecto, Aristófanes, que no duda en situar a Sócrates entre los sofistas como portavoz insigne de una nueva educación para los ciudadanos, denuncia en las Nubes que Sócrates es uno de los nuevos educadores que corrompen a los jóvenes atenienses y, en definitiva, que impulsa el deterioro moral y la decadencia cultural de la ciudad-estado.

Diversa — cuando no opuesta — respecto a la tradición heredada, la protofilosofía es tachada por numerosas voces de anómala y de perniciosa. Además, no sólo resulta sospechosa la novedad didáctica o la actitud vinculada con los albores de la filosofía, sino que algunas de las cuestiones tratadas por ella también son señaladas como estrafalarias o banales. En tanto que la filosofía no constituye propiamente una profesión y que su materia de análisis no responde a primera vista a una cuestión pragmática o utilitaria, se denuncia la actividad filosófica como una ocupación baldía, un pensar vano o una simple charlatanería. No sólo le plaisir de parler de los sofistas, sino la preocupación astronómica de algunos precursores de la filosofía hizo que algunas voces críticas lanzasen sus dardos contra esta actitud ${ }^{6}$, tildándola de meteorología, en un sentido claramente despectivo, a saber, el de estar totalmente desvinculada de las tareas de la ciudad-estado. Sin duda, la acusación tiene fundamentos; por ejemplo, Anaxágoras, del que Platón señala que era un hombre preocupado por el estudio de los fenómenos celestes $\left[\mu \varepsilon \tau \varepsilon \omega \rho \circ \lambda \gamma_{\gamma}{ }^{\alpha} \alpha\right]^{7}$, al ser preguntado sobre la razón de escoger antes existir que no existir, respondió que para contemplar el cielo y el orden de todo el universo (cf. Aristóteles, Ethica Eudemia 1216a13-15). Asimismo, destacables resultan las noticias sobre Pitágoras y los pitagóricos, de cuya profunda influencia en la filosofía platónica prácticamente nadie $\mathrm{duda}^{8}$ y que, entre otras cuestiones, se

${ }^{6}$ Por poner un ejemplo paradigmático, Diógenes Laercio vincula la investigación de los fenómenos astrales al que para muchos es considerado como el primer precursor de la filosofía, a saber, Tales de Mileto (cf. Diogenes Laercio, Vidas y opiniones de los filósofos ilustres, 1.23.1-1.24.7). Por su parte, Heródoto (1.74) afirma del Milesio haber predicado un eclipse en la segunda década del siglo VI a.C.

7 Cf. Platón, Fedro 270a. Véase asimismo Platón, Apología de Sócrates 26d, donde Platón vincula una vez más al de Clazomene con investigaciones astronómicas.

8 Si bien en absoluto se limita a dichos textos, el eco pitagórico es especialmente marcado en el Fedón y en el Timeo, diálogos en los que se aprecia con nitidez la influencia de esta secta filosófica en las concepciones anímica y cósmica del Académico. Así, resulta innegable que Platón bebió de las doctrinas de Alcmeón de Crotona al exponer su teoría anímica, entre otras obras, en el Fedro y, análogamente, es indudable que las doctrinas cosmológicas del Timeo se inspiraron en las teorías de otro pitagórico de Crotona, a saber, Filolao, por más que 
dedicaron a la contemplación [ $\theta \varepsilon \omega$ pía $\left.^{9}\right]$ de los astros y de las armonías cósmicas ${ }^{10}$. Algunos precursores de la filosofía se ocuparon del estudio de los fenómenos celestes, lo cual dio pie a que surgieran críticas del tipo señalado, que, pronto, terminaron por constituir un cliché.

Tal vez, el ejemplo más paradigmático de una acusación semejante la hallemos en las Nubes de Aristófanes, en la que Sócrates y los restantes miembros del pensatorio son presentados de manera ociosa, preocupados por quehaceres vanos, entre ellos, otear constantemente el cielo. El que fuera acusado de impiedad y corromper a los jóvenes es presentado en esta comedia rechazando la existencia de las divinidades tradicionales y venerando a unas nuevas deidades, a saber, las Nubes. Así pues, Aristófanes actúa como portavoz del sector crítico de la ciudad, que juzga que la actividad filosófica no sólo es anómala y perniciosa, sino que en buena medida está desligada de los quehaceres de la ciudad-estado, en tanto que pensar celeste o vacío. Su Sócrates se niega a rendir culto al sistema habitual de divinidades, pues la auténtica divinidad de los humanos son para él las Nubes (cf. 250-252; 316-318; 365), el Aire y el Éter (cf. 263-265), o, también, las Nubes, el Espacio Infinito [Xóos] y la Lengua (cf. 423-424). En consonancia, el comediógrafo muestra al filósofo venerando a las nubes o refiriéndose a ellas con respeto santo en reiteradas ocasiones (cf. 269-274; 291-292; 296-297; 316-318).

Si bien la preocupación por las nubes del Sócrates aristofánico hace evidente qué tipo de crítica se lanza contra los estandartes de la protofilosofía, el ataque va más allá. Además de con las nubes, Aristófanes vincula en reiteradas ocasiones a Sócrates y los sofistas con el análisis de otras materias celestes. Así, cuando

las palabras de Diógenes Laercio, a buen seguro, constituyan una exageración maliciosa (cf. Diogenes Laercio, Vidas y opiniones de los filósofos ilustres, 1.23.1-1.24.7).

9 Un pasaje de Diógenes Laercio muestra a las claras la vital relevancia que le conferían los pitagóricos a la contemplación $[\theta \varepsilon \omega \rho i ́ \alpha]$, de modo análogo a como hizo posteriormente Platón: "Y [Pitágoras] comparaba la vida a una verbena: pues así como en ésta unos acuden para competir, otros para hacer negocios, pero los mejores como espectadores [ $\theta \varepsilon \alpha \tau \alpha i ́]$, así en la vida unos nacen esclavos, perseguidores de la fama y del enriquecimiento, otros filósofos, perseguidores de la verdad" (Cf. Diógenes Laercio, Vidas y opiniones de los filósofos ilustres, 8.8. Trad. L.A. Bredlow).

${ }^{10}$ El propio Platón cita a los pitagóricos en su República, vinculándolos con los quehaceres mentados: "Da la impresión de que, así como los ojos han sido provistos para la astronomía

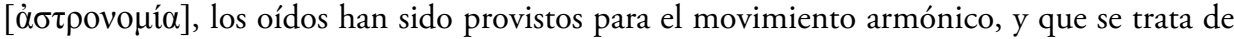
ciencias hermanas entre sí, como dicen los pitagóricos" (República 530d6-8. Trad. de C. Eggers Lan). Por su parte, Aristóteles parece apuntar en la misma dirección (cf. Acerca del Cielo 290a12-291a28) al señalar que la teoría de las esferas armónicas, que aunaba la astronomía y la armonía, era ya defendida por los pitagóricos. 
Estrepsíades le describe a su hijo Fidípides el pensatorio, entre otras cuestiones, señala que en él habitan hombres que hablan sobre el cielo [oủpavós] (cf. 95-96). En consonancia con esto, cuando el padre entra por vez primera en el pensatorio, un discípulo de Sócrates refiere una anécdota en la que este último examina boquiabierto el recorrido y las revoluciones de la luna (cf. 171-173). Posteriormente, el mismo discípulo alude a un alumno que mirando con el ano

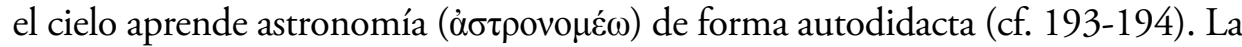
relevancia que adquiere la astronomía en el pensatorio es manifiesta, al ser referida nuevamente por el discípulo unos versos más tarde y ante el asombro de Estrepsíades (cf. 200). Sócrates es presentado suspendido en el aire (cf. 218), surcándolo y reflexionando acerca del sol (cf. 225). Más todavía, el propio Sócrates habla sobre su investigación acerca de las entidades celestes [ $\tau \grave{\alpha} \mu \varepsilon \tau \varepsilon \dot{\varepsilon} \omega \rho \alpha \pi \rho \alpha ́ \gamma \mu \alpha \tau \alpha]$ y señala que de no suspender en el aire su mente y su pensamiento, mezclando sutilmente este último con el que es su igual ${ }^{11}$, i.e. el aire [åńp] (cf. 227-230), no sería capaz de descubrirlas correctamente. El filósofo, por tanto, es descrito como alguien preocupado principalmente por las cosas de arriba $\left[\tau^{\prime} \not \ddot{v} \omega \omega\right]-\mathrm{y}$ no tanto por las de las de abajo, es decir, por las de la ciudad ${ }^{12}$ - . Así, Sócrates, el más ilustre paradigma de la novedosa educación, es dibujado ofreciendo explicaciones celestes o meteorológicas (cf. 365-407). El hijo de Sofronisco y Fenareta trata de hacer a Estrepsíades partícipe de su saber, es decir, trata de iniciarlo en la actitud que estamos denominando "protofilosófica» y, para ello, le pide que

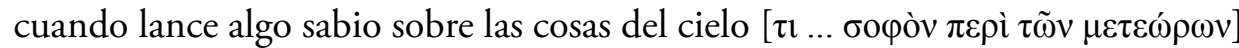
trate de cazarlo al vuelo directamente (cf. 489-490).

La crítica de Aristófanes no es gratuita, sino que existen numerosas noticias de que los denominados "filósofos presocráticos» y algunos de los sofistas se dedicaron a investigar los fenómenos celestes ${ }^{13}$. Ahora bien, la crítica no sólo recoge una cuestión histórica, sino que la interpreta de manera malintencionada, haciendo ver que tales ocupaciones son del todo triviales o inútiles. Con sorna manifiesta Aristófanes muestra a través de las intervenciones de Estrepsíades lo

\footnotetext{
${ }_{11}$ El objetivo de dicha burla parece ser la antiquísima creencia compartida por numerosos protofilósofos, según la cual el alma y el pensamiento eran de la misma naturaleza que el aire o el éter. Además, la crítica iría dirigida contra la opinión de que lo semejante se conoce a través de lo semejante, que Empédocles, entre otros, sostendría.

12 La escuela de Atenas de Raffaello ofrecería cierta continuidad de la opinión de que la filosofía socrática, continuada por Platón, se ocupa de las cuestiones de arriba.

13 Sirva de ejemplo el pasaje platónico en el que se dice que en una ocasión, en casa de Calias, una serie de personas le preguntaban a Hipias de Elis acerca de cuestiones astronómicas, así como sobre la naturaleza y los entes celestes (cf. Platón, Protágoras 315c).
} 
ridículo que resultan estas ocupaciones (cf. v. gr. 293-295). Así, tras dialogar con Sócrates y escuchar al coro de nubes, Estrepsíades afirma que gracias a haber oído

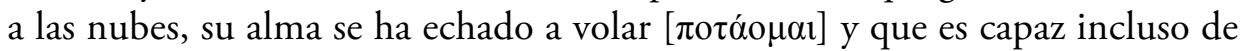

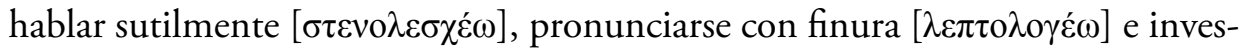

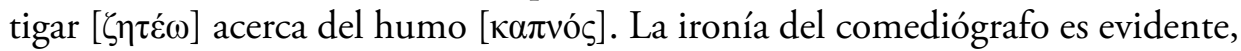
sugiriendo que los que se ocupan de este tipo de cuestiones no son sino gente rústica que, arrogándose una banal y ridícula sutileza a la hora de hablar, avanzan por el mundo con aires de grandeza como si su alma fuese algo alado y que se eleva por encima de los restantes mortales. No en vano Aristófanes se encarga de mostrar la arrogancia de Sócrates en pasajes como Nubes 223, en el que interpela a su interlocutor Estrepsíades mediante el vocativo «efímero».

De hecho, la arrogancia filosófica parece ir en consonancia con otra de las características históricas de la protofilosofía. Algunos de los precursores de la filosofía, como los pitagóricos, se congregaban en grupos reducidos, conocidos normalmente como sectas ( $\alpha i \rho \varepsilon ́ \sigma \varepsilon ı \varsigma)$, y su saber era guardado con celo en el interior de la comunidad, con notorio carácter iniciático y mistérico. La secta está formada por los iniciados, frente a los restantes, que por no haber sido iniciados permanecen en la ignorancia ${ }^{14}$ y no participan del grupo. Pues bien, Aristófanes parece hacerse eco de esto, de nuevo con un sarcasmo evidente, dibujando a los habitantes del pensatorio como una secta iniciática y en la que para ser introducido es necesario pasar por un rito iniciático (cf. 143-147; 254-275; 308-313).

En resumidas cuentas, Aristófanes ofrece un claro ejemplo de las críticas más comunes vertidas contra los precursores de la filosofía, que como un cliché eran repetidas por aquellos que denunciaban la anomalía del comportamiento de aquéllos ${ }^{15}$. Lo hace además de una manera general, sin preocuparse en absoluto por establecer distinciones entre las diferentes posiciones que constituyen los antecedentes más decisivos para la empresa platónica. Las Nubes constituyen así

14 Por citar un ejemplo, algunos fragmentos de Heráclito de Éfeso (cf. DK B1; B2) dejan clara la distinción entre el vulgo y aquel que consigue adquirir un conocimiento privilegiado acerca de la realidad.

15 El propio Platón evidencia que tales acusaciones constituían un cliché en la Atenas de su época. En Apología de Sócrates 23d4, Sócrates señala que los que lo critican, cuando son interrogados acerca de sus prácticas y enseñanzas, al no saber nada sobre éstas y al verse en la necesidad de responder algo para no quedar en mal lugar, echan mano de los tópicos, empleando las críticas que habitualmente son vertidas contra todos aquellos que filosofan, a

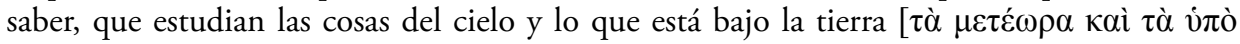
$\gamma \tilde{\eta} \varsigma]$. 
una valiosa caricatura, que retrata el modo en el que muchos sectores ciudadanos veían lo que constituyó el germen de la incipiente filosofía.

\section{Platón, conocedor de la parodia contra la filosofía}

Lejos de ignorar tales críticas o de rechazar que su proyecto filosófico pueda ser criticado en dichos términos, Platón no oculta que el filósofo se comporta de manera anómala respecto al resto de conciudadanos y que, al menos aparentemente, el carácter de sus investigaciones y su manera de proceder distan en gran manera del hacer ordinario de sus vecinos. Se ha mostrado que desde diversos sectores se critica la anomalía [à̃o $\pi i^{16}{ }^{16}$ que supone la corriente ilustrada que precede a su filosofía. Pues bien, Platón muestra sin ambages en sus diálogos que el personaje que en buena medida es el estandarte de su propuesta filosófica y, por ende, el paradigma de la actitud filosófica, es alguien anómalo [äto

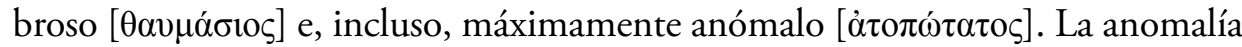
y extravagancia cívica de su Sócrates, es decir, lo extraordinario de lo que dice, de su actitud y sus prácticas, es reflejada en los Diálogos en numerosos pasajes, especialmente, a través de sus conciudadanos e interlocutores (cf. v. gr. Apología de Sócrates 31c4; Fedón 62d1; Gorgias 473a1, 494d1; Alcibiades I 106a9; Banquete 215a; Fedro 230c6, 257c5). Su actitud está fuera de lugar, resulta inquietante y causa aporía entre sus conciudadanos (cf. Teeteto 149a9). La actitud del filósofo Sócrates resulta desconcertante, más incluso, resulta incómoda para muchos y por ello se le condenó a muerte (cf. Solana Dueso, 2013).

Por tanto, Platón no niega que la filosófica constituya una actitud anómala en la ciudad, sino que, más bien, lo reconoce. Sin duda, no niega que la filosofía se manifieste a simple vista como una praxis excéntrica y, por tanto, no se extrańa de que para la mayoría, es decir, para los que no están versados en ella, se trate de una ocupación huera y que desatiende los quehaceres ordinarios. Precisamente, Platón parece querer afirmar en un pasaje del Teeteto que la filosofía desde sus primeros albores estuvo constantemente expuesta a la incomprensión de la

\footnotetext{
${ }^{16}$ Este término, que sirve para designar la anomalía, literalmente significa «sin lugar», es decir, «fuera de lugar». Pese a que Sócrates abandonó en muy pocas ocasiones su ciudad, a los ojos de sus conciudadanos se muestra desconcertante, es decir, como si no se encontrase en su hábitat natural o estuviese fuera de lugar, venido de un mundo con convenciones y prácticas diversas. Sobre la amplitud del sentido del término aquí referido, cf. Hadot, 2008, 47-48.
} 
ciudad y, por tanto, tachada de extravagante. Para ello el Académico se refiere al que Aristóteles atribuye ser el primer filósofo que analiza la causa material como el principio de todo cuanto es (cf. Metafísica 983b20-21) y al que, en general, se le ha solido considerar el primer precursor de la filosofía. Platón pone en boca del que fuera su maestro lo que sigue:

Es lo mismo que se cuenta de Tales, Teodoro. Éste, cuando estudiaba los

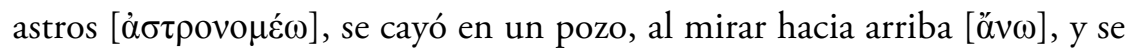
dice que una sirvienta tracia, ingeniosa y simpática, se burlaba de él, porque

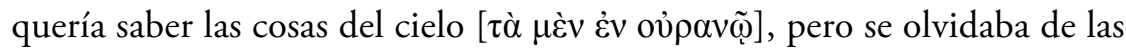
que tenía delante y a sus pies. La misma burla podría hacerse de todos los que dedican su vida a la filosofía (174a4-b1. Trad. de A. Vallejo Campos).

Al fundador de la Academia no le pasaba desapercibido que, como Aristófanes expone, el filósofo es visto por buena parte de sus conciudadanos como alguien excéntrico y aéreo, dedicado a cuestiones abstractas y desatendiendo las ocupaciones más apremiantes, entre ellas, la política. Tales es empleado en este texto como paradigma del filósofo, y se subraya la incomprensión y sorna a la que da pie su actitud.

Lejos de constituir un pasaje puntual, esta misma idea se ve reflejada en numerosas obras del $\operatorname{Corpus}^{17}$. A continuación ofrecemos un breve análisis de dicha cuestión atendiendo al Fedro, en tanto que en él numerosos pasajes subrayan la extrañeza del filósofo, a menudo, en términos muy similares a los empleados por Aristófanes y que constituían un lugar común para caracterizar al filósofo. En este diálogo, la anomalía, la meteorología y el toque iniciático del filósofo, así como la incomprensión de sus conciudadanos, son puestos de manifiesto.

17 Significativo es a este respecto un pasaje de la República en el que Adimanto le señala a Sócrates que, pese a que gracias a su habilidad discursiva haya logrado mostrar al filósofo como alguien excelso y útil para la ciudad, lo cierto es que muchos ciudadanos opinan que, en la práctica, los que se dedican a la filosofía son unos inútiles: "en su mayoría [los que se

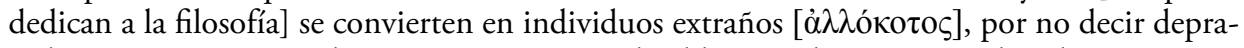

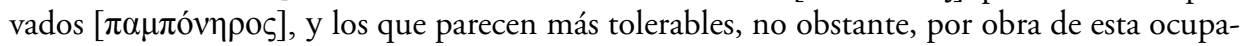

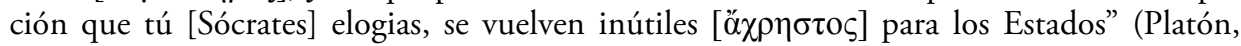
Rebública 487d. Trad. C. Eggers Lan). Lejos de sorprenderse, Sócrates muestra a las claras que conoce dichas críticas y que es consciente de que la ciudad acostumbra a caracterizar al filósofo como un "observador de las cosas que están en lo alto [ $\mu \varepsilon \tau \varepsilon \omega \rho о \sigma \kappa o ́ \pi o \zeta]$, charlatán

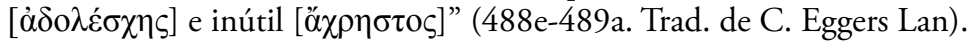


Tal y como se ha señalado, el interlocutor de Sócrates, en este caso Fedro de Mirrinunte, en algunas intervenciones expresa su extrañeza frente a aquél

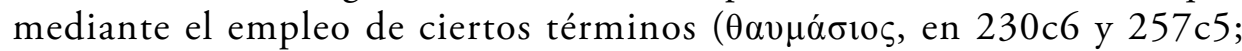

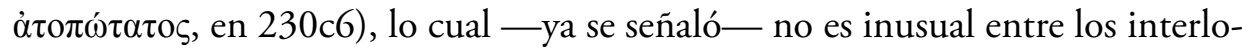
cutores platónicos que dialogan con Sócrates. El filósofo se muestra asombroso ante los interlocutores y conciudadanos que no están versados en la filosofía.

De manera más significativa, en un pasaje del diálogo donde se discurre sobre las condiciones universales para escribir o hablar bien, es decir, sobre las condiciones generales para dominar el arte retórico, Sócrates sostiene que para ello — como es necesario, por lo demás, en todas las artes relevantes - es preciso

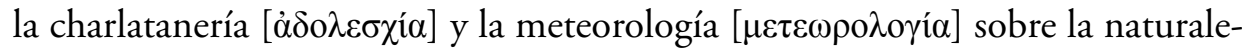
za [ $\pi \varepsilon \dot{\varepsilon} \rho \iota v ́ \sigma \varepsilon \omega \varsigma]$. El motivo que justifica esta necesidad es que a partir de éstas

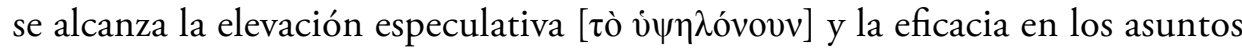

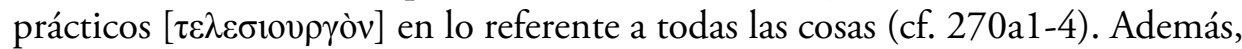
añade que, en ese sentido, Pericles fue el orador más cumplido, en buena medida, merced a que se colmó de meteorología gracias a Anaxágoras.

$\mathrm{Al}$ analizar la crítica de Aristófanes, se comprobó que éste recurre con insistencia al tópico de caracterizar la filosofía como una meteorología o análisis de los entes celestes. Platón no rehúye esta acusación, sino que parece aceptarla de forma más o menos irónica ${ }^{18}$. Una de las tesis del filósofo en el Fedro es que la auténtica retórica es la dialéctica, es decir, la filosofía (cf. Trabattoni (ed.), 1995, 178; Cassin, 1995; Bonazzi (ed.), 2011, 32; Tordesillas, 2013, 261-262, n. 18), y, por tanto, en el pasaje citado, el Académico estaría aludiendo a la filosofía mediante el término «meteorología», como por lo demás se intuye al relacionarlo con Anaxágoras, el cual es habitualmente catalogado como otro de los precursores de la actitud filosófica y del que nos han llegado noticias que lo vinculan con la astronomía (cf. v. gr. Platón, Apología de Sócrates 26d4-e2;

\footnotetext{
${ }_{18}$ Podría objetarse, tal vez, que en Apología de Sócrates 18b4-c3 el Sócrates platónico mani-

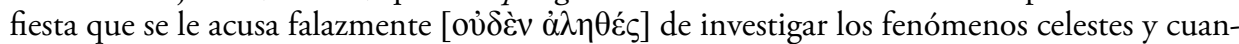

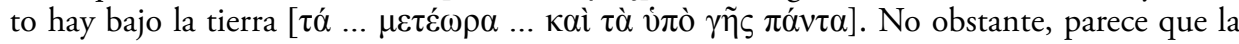
intervención socrática no busca tanto desmentir esto — de hecho, el presente artículo muestra que Platón vincula a su Sócrates con dicha práctica en varios textos del Corpus-, sino señalar que dichas acusaciones han llevado a la ciudadanía a creer erróneamente que es impío - téngase presente que no se le acusa de dedicarse a la meteorología, sino de ser impío-, ya que se

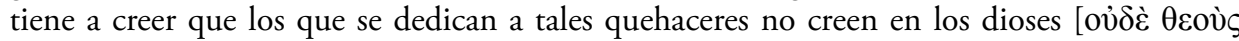

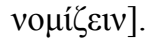


Plutarco, Pericles 4.6.1-5.2.1; Diógenes Laercio, Vidas y opiniones de los flósofos ilustres, 2.8.1-2).

Análogamente, la crítica de Aristófanes en las Nubes también caracteriza la actividad de Sócrates y sus camaradas como una charlatanería (cf. Nubes 1480), y Estrepsíades designa el pensatorio mediante la expresión "casa de los charlatanes»

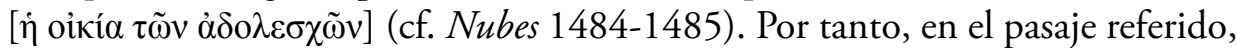
cuando se dice que para dominar la técnica retórica es preciso charlatanear y meteorologizar sobre la naturaleza, con una clara ironía contra sus críticos, Platón estaría defendiendo por boca de Sócrates que para ser un orador excelso es preciso practicar la filosofía. En cualquier caso, lo que resulta más relevante por el momento es constatar que Platón caracteriza su propia actividad mediante algunos de los clichés que emplean sus adversarios para criticarla.

Dicho esto, la estrategia platónica de definir en el Fedro su filosofía mediante algunas de las expresiones empleadas por sus críticos va más allá. En el pasaje en el que se narra el mito de las cigarras (cf. 258e6-259d8) Sócrates sostiene que las Musas asociadas a la filosofía son Calíope y Urania [Oủpavía] (cf. 259d3-5). En lo que concierne al objetivo del presente texto, la alusión a la primera Musa no resulta excesivamente relevante, pero la segunda, en cambio, sí, en tanto que mediante ella se vuelve a ligar la filosofía con lo celeste. Según dice el propio Sócrates tras pronunciar el nombre de estas dos Musas y asociarlas a los filósofos, estas deidades son las que se ocupan principalmente del cielo [ $\pi \varepsilon \rho i ́$... oủpavòv] y de los discursos divinos y humanos. El nexo etimológico entre Urania [Oủpavía] y el cielo [oủ $\alpha$ vóc] es evidente. La celeste Urania es considerada como la patrona de la astronomía (cf. Brisson (ed.), 2004, 220, n. 310; Sala, 2007, 224) ${ }^{19}$. De este modo, Platón vuelve a ligar su filosofía con la meteorología y la astronomía, de modo análogo al que lo hicieron sus críticos.

El discurso conocido como la "palinodia» (cf. 243e-257b) acentúa, más si

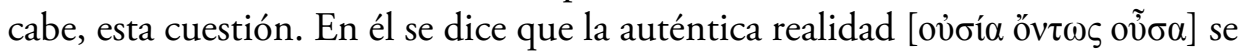

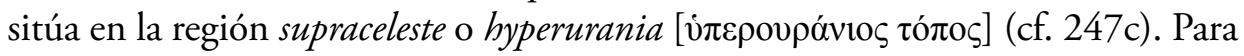
que el alma conozca de modo verdadero e infalible la realidad, el método no es otro que alzarse hasta el límite de la bóveda del cielo y contemplar las entidades situadas más allá de su linde. Si bien el alma encarnada en un cuerpo no puede

19 Conviene señalar que referirse a Urania como Musa de los filósofos podría suponer una alusión al pitagorismo (cf. Boyancé, 1946, 3-16; de Vries, 1969, 194-195), a saber, otra de las sectas protofilosóficas de las que surge la filosofía. 
gozar de una experiencia semejante, en un estado previo a la encarnación, toda alma participa de un proceso tal, en lo que constituye una procesión celeste que sigue los pasos de las divinidades (cf. 246a-248c). Nuevamente puede apreciar-

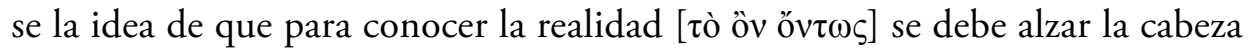
[ảvakv́ $\tau \omega$ ] (cf. 249c3-4), pues aquélla se encuentra arriba, más allá incluso de los confines del cielo, en lo que Sócrates designa hyperuranios topos o llanura

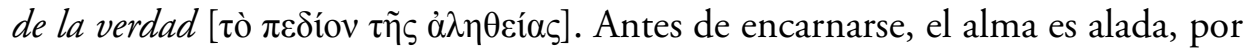
lo que tiene la propiedad de elevarse hacia lo alto, es decir, de volar. Gracias a esto, en la procesión celeste de los dioses en la que siguen los pasos de las divinidades, el alma puede elevarse por el cielo y contemplar la realidad. Por tanto, en la palinodia el tópico del filósofo como un ser aéreo vinculado con el cielo y que mira hacia arriba está muy presente. De modo análogo a como Tales y los demás meteorólogos miran hacia arriba, en Platón el conocimiento de la realidad, al menos en el estado desencarnado del alma, se vincula con el cielo y se realiza gracias a una visión directa ${ }^{20}$ de lo que hay en el hyperuranios topos.

Previamente a encarnarse, el alma humana pierde su status alado y, por tanto, no le es posible conocer de una manera similar a la descrita en la palinodia. El alma encarnada no puede elevarse por el cielo y alzar la cabeza hacia lo alto; para hallar la verdad es preciso recurrir a un proceso indirecto, es decir, a una especie de segunda navegación ${ }^{21}$, que consiste en lo que se conoce como dialéctica y reminiscencia. La extrañeza del filósofo reside, precisamente, en que no se preocupa en primer término de lo que en el mundo de aquí abajo denominamos «realidad», sino por las entidades que realmente son y que se sitúan en la región supraceleste, a saber, lo que se conoce como Ideas o Formas. El motivo en absoluto responde a una negligencia respecto a las cuestiones mundanas, sino a la convicción de que para discurrir correctamente sobre estas últimas es preciso investigar antes sobre las Ideas, pues ellas constituyen la verdad y es a partir de ellas como puede fundarse un criterio sólido sobre las cosas de abajo. En cualquier caso, en tanto que el filósofo afirma investigar sobre la auténtica realidad o las Ideas, las cuales se hallan más arriba incluso que la bóveda celeste, es considerado por la mayoría de sus conciudadanos como alguien anómalo, que se preocupa por cuestiones de otro mundo. Platón es consciente y lo expresa de manera más o menos nítida

\footnotetext{
${ }^{20}$ En el pasaje de la palinodia en el que se describe la procesión celeste del alma desencarnada para nutrirse de la verdad (cf. $246 \mathrm{~d} 6$ y 248c2), existe una clara acumulación de términos

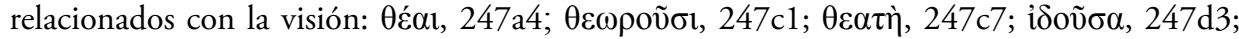

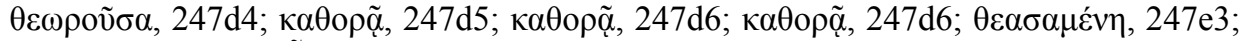

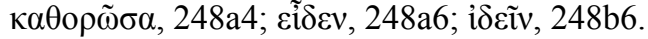

${ }^{21}$ Sobre el significado de esta expresión del Fedón, véase Martinelli Tempesta, 2003.
} 
en el Fedro, comparando a aquel que ama de una manera correcta, es decir, el filósofo, con un ave (cf. 249d7-8).

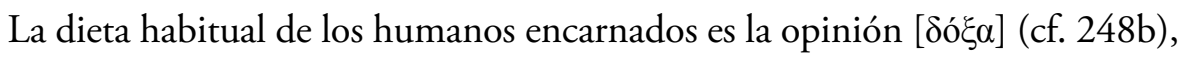
pues al perder sus alas y corporeizarse olvidan todo lo relativo a lo que vieron en su procesión celeste (cf. 248c), creyendo que no existe nada más que lo que pueden divisar en su nuevo estado a través de los sentidos. Por tanto, fruto del desconocimiento, el deseo del alma del humano encarnado suele orientarse hacia realidades sensibles. El filósofo platónico, en cambio, es aquel que comprende - que llega a recordar - que el objeto natural de deseo del alma no se encuentra en este mundo, sino en la región hyperurania. El alma desea por naturaleza las Ideas, pues ellas son su auténtico alimento (cf. 248b-c), y el filósofo decide ofrecer al alma aquello que desea por naturaleza, a saber, el conocimiento

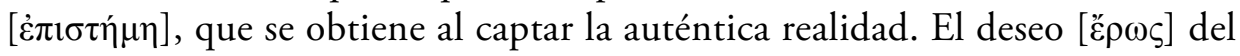
filósofo tiene esta particularidad, que no se orienta hacia lo mundano, sino que partiendo de él, persigue lo que es auténticamente bello, a saber, las Ideas. En su palinodia, Sócrates describe esta idiosincrásica manera de amar del filósofo, nuevamente, vinculando su figura con la de un ser aéreo. Afirma que el amor filosófico se produce cuando alguien contempla la belleza de este mundo y, acor-

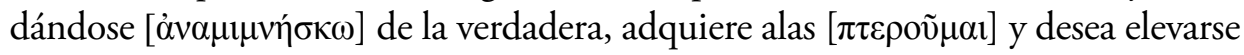

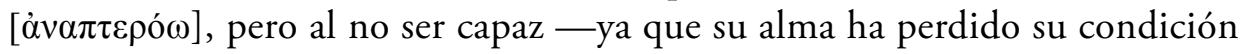

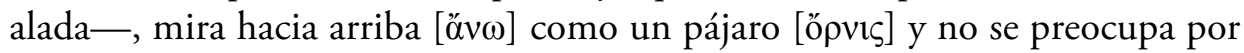
las cosas de abajo [ $\kappa \alpha ́ \tau \omega]$, siendo ésta la causa que lo tomen por loco (cf. 249d).

El relato muestra a las claras que el filósofo es percibido como alguien anómalo, es decir como un loco, pues los restantes no comprenden el motivo de su manera de actuar. El filósofo es visto por los demás como un ave que mira hacia lo alto y que quisiera echarse a volar. Téngase presente que tras escuchar a las nubes, es decir, tras meteorologizar, el propio Estrepsíades se siente como si su alma fuese a echar a volar (cf. Nubes 319-322). El filósofo, cuando se ocupa de sus actividades más genuinas, a saber, la dialéctica y la reminiscencia — que para los críticos constituiría una mera meteorología-, es considerado por los demás un loco, preocupado por cuestiones celestiales y aéreas, rindiendo culto a Urania, como si pretendiese echarse a volar.

Una vez comprobado que Platón era plenamente consciente de cómo interpreta el vulgo la actividad filosófica, conviene mostrar sucintamente que también recoge en el Fedro otra de las características que destacan los críticos de la filosofía y que emplean como dardo contra ella, a saber, su cariz mistérico e iniciático. 
Según ha sido señalado por los comentaristas, algunos pasajes de este diálogo aluden de manera más o menos clara a los Misterios de Eleusis. Como han apreciado algunos autores ${ }^{22}$, la palinodia a la que se acaba de aludir vincula la filosofía con un tipo de rito iniciático, entre otras cuestiones, introduciendo el lenguaje y las imágenes propias de tales ceremonias. Sin ir más lejos, en Fedro 249c7-8 el

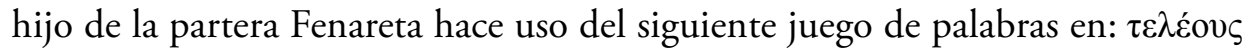
... $\tau \varepsilon \lambda \varepsilon \tau \grave{\alpha} \varsigma \tau \varepsilon \lambda o v ́ \mu \varepsilon v o \varsigma, \tau \varepsilon \dot{\lambda} \varepsilon o \varsigma$. Adviértase que el verbo $\tau \varepsilon \lambda \varepsilon \dot{\omega} \omega$ significa «cumplir»,

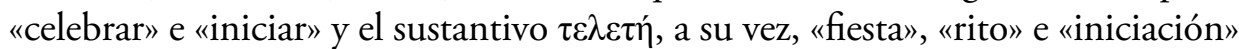
(cf. Velardi (ed.), 2006, 198, n. 150). El nexo establecido en la palinodia entre la filosofía y un rito iniciático constituye, tal vez, el indicio más relevante a este respecto — recuérdese que en Nubes 143-147, 254-275, 308-313 la actividad del pensatorio es vinculada a cierto proceso iniciático-, pero no es el único. Así, el lugar por el que caminan los dos interlocutores en el inicio del diálogo ${ }^{23}$ y el mito de Oritía y Bóreas (229a-230a) han sido relacionados con los Misterios de Eleusis (cf. Wasson \& Hofmann \& Ruck, 1978, 58-59). Análogamente, según algunos, los pasajes del velo ${ }^{24}$ socrático (cf. 237a4-5; 243b4-7) también contendrían una alusión a los Misterios y a ritos iniciáticos (cf. Velardi (ed), 2006, 146-147, n. 4).

La atmosfera ritual e iniciática que se le reprocha a la filosofía, por tanto, también estaría recogida en el Fedro. En cualquier caso, conviene ser cautos, sobre todo, a tenor de las noticias que tenemos de que el Fedro histórico fue condenando al exilio por haber parodiado los Misterios de Eleusis ${ }^{25}$. Así pues, las constantes alusiones a los Misterios y a la iniciación bien podrían deberse a ello. De lo que no cabe duda es que Platón es consciente de que la filosofía es vinculada por muchos a una actitud anómala. Él mismo dibuja al estandarte de su proyecto filosófico como alguien enigmático, recogiendo además en torno a la figura de Sócrates algunos de los clichés con los que se acostumbra a atacar a la filosofía.

22 Por ejemplo, Kerényi (2004) es uno de los autores que recientemente han sostenido que, en Fedro 249c y Fedro 250b-c, el fundador de la Academia emplea el lenguaje y las imágenes de los Misterios de Eleusis para caracterizar su filosofía.

${ }^{23}$ Kerényi $(2004,69)$ y Werner $(2012,22-23)$ son algunos de los autores que vinculan el lugar descrito cabe el río Ilisos, los campos de Agra, con los Misterios.

${ }_{24}$ En las Nubes de Aristófanes, en un pasaje en el que se parodia la iniciación filosófica que Sócrates practica sobre Estrepsíades, este último, que parece no percatarse del asunto, expresa su voluntad de cubrirse con un manto (cf. Nubes 267).

25 Sobre esta cuestión y otras informaciones sobre el personaje histórico, cf. Nails, 2002, 232234. 


\section{La inversión platónica}

Al menos en cierta medida, el más ínclito de los discípulos de Sócrates concuerda en que la filosofía va ligada de algún modo a una actitud que a primera vista a la ciudad, como a la esclava tracia del relato sobre Tales, le parece ridícula, fuera de lugar y desligada de las ocupaciones ciudadanas. Aparentemente, la actividad filosófica resulta desconcertante y descuida las cuestiones mundanas en favor de otras, que se muestran aéreas o fútiles ${ }^{26}$. No obstante, si Platón se hace eco de esas críticas y las incluye en sus diálogos, sin duda, no lo hace para claudicar ante sus enemigos. Al contrario, el objetivo platónico es el de invertir dichas críticas, mostrando que lo que algunos tachan de absurdo o anómalo, en realidad, es extraordinario y máximamente conveniente. Diálogos como el Fedro recogen los clichés lanzados contra la filosofía, pero para ponerlos patas arriba mediante la ironía, mostrando que la anomalía filosófica, si es considerada con detenimiento, se muestra como la actitud más apropiada y sensata para el humano. A continuación, el presente texto recoge algunas de las claves para comprender el sentido de esta inversión irónica de los diálogos —en este caso

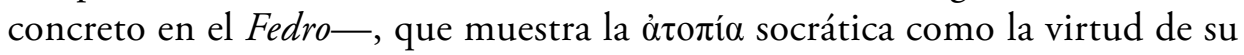
maestro y ceguera de los que lo condenaron a muerte.

La clave para rastrear esta operación se halla en la palinodia. Una lectura atenta permite captar la ironía socrática —o platónica si se prefiere- De forma análoga a como en la comedia aristofánica acostumbra a producirse una inversión

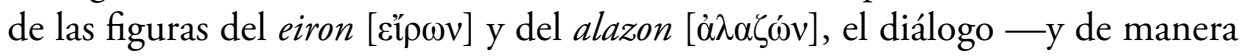
privilegiada la palinodia — invierte la aparente anomalía filosófica, mostrando que la actitud del filósofo no sólo es la más sensata, sino la más ajustada a la propia naturaleza del alma humana y que, por tanto, debería constituir la dispo-

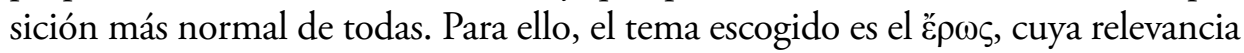
resulta central a la hora de caracterizar la naturaleza de la filosofía.

Como su etimología manifiesta, la filosofía consiste en amar [ $\varphi \imath \lambda \varepsilon \dot{\varepsilon} \omega]$ la sabi-

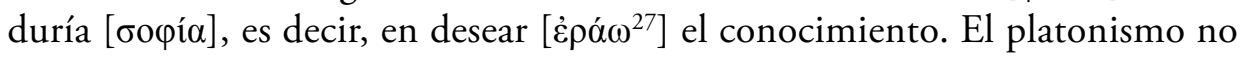
sólo reconoce sin tapujos que la situación cognoscitiva inicial del humano es

\footnotetext{
26 En un valioso artículo, Cooper (2005, 77-96) señala que para algunos contemporáneos de Platón, y en concreto para Antístenes, la filosofía platónica sería yerma o inútil en lo que atañe a la vida comunitaria de los ciudadanos.

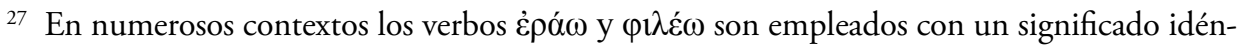
tico.
} 
precaria, sino que concluye que por más que podemos tratar de revertir dicha situación y avanzar en el conocimiento, el humano nunca puede llegar a alcanzar la omnisciencia y la certeza, es decir, no puede llegar a ser sabio [бoфós] (cf. v. gr. Apología de Sócrates 23a5-7). Por mucho que avancemos en el conocimiento y lo depuremos, nunca podremos alcanzar la omnisciencia. Por ello, a lo máximo que puede aspirar una persona en cuanto a tareas cognoscitivas atañe no es otra cosa que tratar de progresar continuamente en el conocimiento, esto es, ser filósofo, un amante de la sabiduría. El filósofo, por tanto, se halla a medio camino entre el que siendo ignorante ni se percata ni se preocupa de ello y el sabio que todo lo sabe con certeza. De hecho, el propio Eros es caracterizado en el Banquete como un filósofo 28 -es decir, como un alter ego de Sócrates - en tanto que es un amante de lo bello (cf. Banquete 203c-4 y 203d7). Con la estrategia de definir la filosofía, Platón pone en boca de Sócrates un mito que supuestamente proviene de Diotima de Mantinea. Según ésta, Eros es hijo de Penía [Пєvía] y Poros [Пópos], esto es, de la pobreza y del recurso respectivamente. Esta genealogía indica la propia condición del filósofo, el cual siempre está ligado en cierta manera a la ignorancia pues su conocimiento no puede ser pleno y seguro-, pero que posee los recursos suficientes para salir adelante en busca de lo que le falta y anhela. Reproducimos a continuación una breve descripción de este ser intermedio, que, como hemos indicado, en el fondo sirve para caracterizar al filósofo:

En primer lugar, es [Eros] siempre pobre, y lejos de ser delicado y bello, como cree la mayoría, es, más bien, duro y seco, descalzo y sin casa, duerme siempre en el suelo y descubierto, se acuesta a la intemperie en las puertas y al borde de los caminos, compañero siempre inseparable de la indigencia por tener la naturaleza de su madre. Pero por otra parte, de acuerdo con la naturaleza de su padre, está al acecho de lo bello y de lo bueno; es valiente, audaz y activo, hábil cazador, siempre urdiendo alguna trama, ávido de sabiduría y rico en recursos, un amante del conocimiento a lo largo de toda su vida, un formidable mago, hechicero y sofista. [...] Eros nunca ni está falto de recursos ni es rico, y está, además, en el medio de la sabiduría y la ignorancia. Pues la cosa es como sigue: ninguno de los dioses ama la sabiduría ni

\footnotetext{
28 ”E $\rho \omega \varsigma$ es designado literalmente como un $\delta \alpha i ́ \mu \omega v$, que constituye un ser intermedio entre lo divino y lo mortal. Pese a que la cuestión de su mortalidad sea compleja, podemos afirmar que el filósofo se sitúa en un estadio intermedio, entre la ignorancia absoluta de la bestia y la condición de sabio del dios. Además, como el Eros, siempre persevera en su intento de poseer lo bueno, lo cual hace que avance siempre — aunque sin poder lograr alcanzarla nunca-

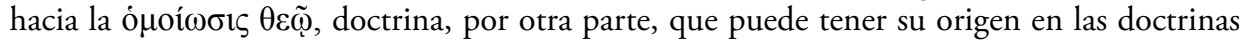
pitagóricas.
} 
desea ser sabio, porque ya lo es, como tampoco ama la sabiduría cualquier otro que sea sabio. Por otro lado, los ignorantes ni aman la sabiduría ni desean hacerse sabios, pues en esto precisamente es la ignorancia una cosa molesta: en que quien no es ni bello, ni bueno, ni inteligente se crea a sí mismo que lo es suficientemente. Así, pues, el que no cree estar necesitado no desea tampoco lo que no cree necesitar (Banquete 203c6-204a7. Trad. de M. Martínez Hernández).

Por tanto, el Académico escoge un tema central de su propuesta, a saber, el eros, para llevar a cabo en el Fedro la inversión irónica que hemos anunciado. El objetivo de Platón es mostrar que amar es constitutivo de la naturaleza humana y que la manera de amar del filósofo, que en definitiva es la que determina el peculiar modus vivendi de quien practica la filosofía, pese a parecer a primera vista anómala, en realidad, constituye la forma erótica que más se ajusta a nuestra naturaleza y a la propia realidad, por lo que es, en suma, la forma más sensata de estimar. Veamos, pues, cómo despliega Platón esta cuestión en dicho diálogo.

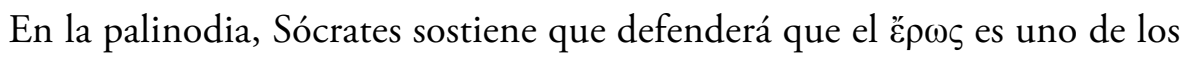
cuatro tipos de locura divina ${ }^{29}$ —es decir, una posesión enviada por los diosesy que, por tanto, lejos de constituir un mal, proporciona a los humanos los más grandes bienes (cf. 245b1-245c4), ya que de lo divino sólo pueden proceder beneficios. En consonancia, puesto que la locura erótica constituye un bien y una gracia divina, Sócrates defiende la tesis de que es preferible estar loco que cuerdo. Expresado diversamente, la palinodia se presenta como un elogio de la locura

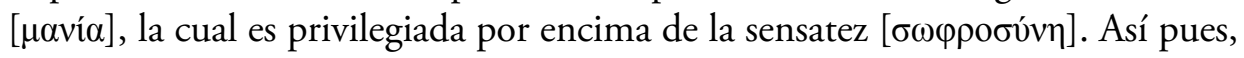
el anómalo Sócrates — un loco para muchos — afirma que se dispone a ofrecer un elogio de esta forma de extravío divino. Sin embargo, una lectura atenta del diálogo muestra que cuanto se expone no es exactamente lo que parece ${ }^{30}$. Si bien Sócrates presenta su segundo discurso - - i.e. la palinodia - como una tesis opuesta a los dos discursos anteriores (cf. 242b-243e) —en los que el है $\rho \omega \varsigma$ es caracterizado como un mal-, lo cierto es que ni su tesis es diametralmente opuesta a las sostenidas anteriormente, ni se elogia realmente la locura. Los dos primeros discursos defienden que el amor constituye un mal para quien lo padece y la palinodia, pese a lo que anuncian las palabras de Sócrates, no lo niega por completo, sino

29 Los tres tipos de locura restantes son la mántica (cf. 244a8-244d5), la teléstica (cf. 244d5-244a1) y la poética (cf. 245a1-245a8).

${ }^{30}$ Rowe ha señalado con gran acierto que en este diálogo nada es exactamente lo que parece (cf. Rowe (ed.), 1988, vii). 


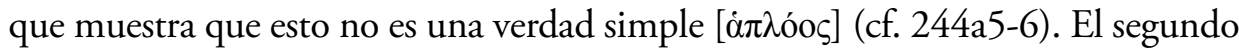
discurso socrático no niega que existan formas nocivas de $\operatorname{amar}^{31}$, sino que más bien sugiere lo contrario (cf. 250e1-251a1; 252c4-8), pese a que descarte tratar sobre ellas -al fin y al cabo, no resulta necesario, pues los anteriores discursos ya lo han hecho ${ }^{32}$ - . En cualquier caso, esta cuestión ha solido pasar desapercibida, sobre todo, ya que Sócrates se limita a explicar la causa primera del amor y

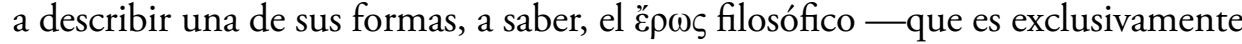
positivo-, fingiendo que el discurso es enteramente opuesto a los dos anteriores.

Siendo en sí misma una pasión positiva, el amor puede canalizarse de una manera beneficiosa, pero también de forma perniciosa ${ }^{33}$. Precisamente, en la palinodia, Sócrates se centra en la forma beneficiosa, a saber, la del filósofo, lo que le permite mostrar su discurso como un elogio del ह̌p $\omega \varsigma$. En ciertos pasajes Sócrates manifiesta de manera muy clara que la causa del amor es siempre una y la misma, pero que muy pocos reaccionan ante este estímulo de la forma más adecuada para el alma, a saber, del modo filosófico, que es precisamente el descrito por la palinodia. Dicho esto, conviene esclarecer cuál es, según dicho discurso, la naturaleza y la causa primera del amor y, a continuación, señalar la particularidad del amor filosófico.

Según se ha indicado previamente, el segundo discurso del hijo de Sofronisco sostiene que el alimento natural del alma son las Ideas (cf. 247c-d; 248b-c). Antes de encarnarse y sin la traba del cuerpo, el alma alada tiende naturalmente hacia lo alto para nutrirse mediante la visión de la auténtica realidad. Dicho de otro

\footnotetext{
${ }^{31}$ En la propia palinodia, Sócrates alude al placer obtenido a través del amor mundano -es decir, el que para el que no es filósofo representa la forma más habitual de amar- como un placer contra natura (cf. 251a1). Pese a que algunos intérpretes hayan sostenido que en este pasaje Sócrates se estaría refiriendo exclusivamente al amor homosexual, lo cierto es que lo más probable es que aluda al amor carnal, ya sea homosexual o heterosexual, tal y como ha defendido Dover (1978, 163, n. 15).

32 Es decir, la palinodia no debe entenderse como enteramente contrapuesta a los diálogos anteriores, sino que ha de completarlos, señalando aquello que a los anteriores se les pasó por alto y propiciando así una comprensión sintética y superadora — dialéctica, si se quiere- del fenómeno erótico.

${ }^{33}$ Esta cuestión viene confirmada en el pasaje Fedro 266a3-266b1, en el que, repasando los discursos anteriores, Sócrates sostiene que se habló de un amor siniestro y de un amor diestro, el primero vituperable y el segundo, en cambio, encomiable. El primer discurso de Sócrates - y también el discurso de Lisias - analiza el amor dañino, mientras que la palinodia examina el amor beneficioso y, además, esclarece la causa primera de toda forma erótica, ofreciendo las claves para poder comprender el ěp $\omega \varsigma$ de forma unitaria y múltiple, es decir, de forma dialéctica.
} 
modo, el alma es atraída naturalmente por las Ideas, que son su auténtica fuente nutricia. Es decir, las almas desean o aman naturalmente las Ideas. La causa de

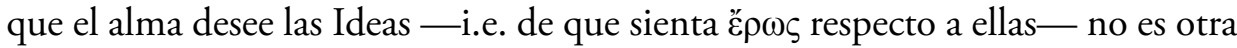
que la belleza de éstas. La auténtica realidad, la que constituye el conocimiento genuino para el alma, es máximamente bella ${ }^{34} \mathrm{y}$, por ello, el alma la desea naturalmente. El eros, en definitiva, no es otra cosa que la atracción que suscita naturalmente en el alma lo bello ${ }^{35}$. Lo auténticamente bello no es sino lo realmente

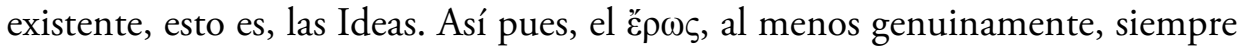
constituye un deseo de ver las Ideas. Ahora bien, si esto es así, ¿por qué le pasa a todo el mundo desapercibido? ¿Por qué la gente no comprende que el amor es

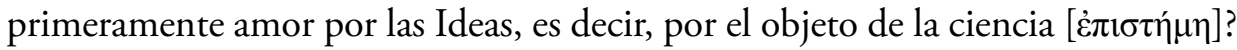

Sócrates lo explica en su discurso: cuando el alma desencarnada pierde las alas, cae a tierra y se encarna, el olvido $[\lambda \eta \dot{\theta} \theta \eta]$ le sobreviene. Entonces, el alma

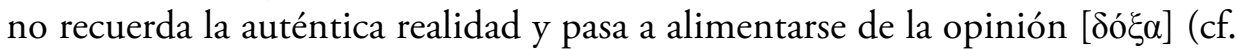
248b). El humano cree que los objetos del mundo de aquí abajo constituyen la auténtica realidad, sin lograr recordar aquello que constituye lo realmente existente y que es su auténtico objeto de deseo y fuente nutricia. Los objetos de este mundo participan de la auténtica realidad, pero el olvido y la precariedad epistemológica del humano, que encarnado en un cuerpo no puede contemplar

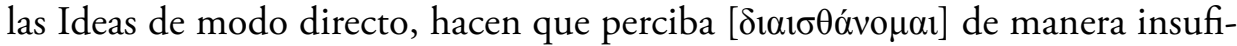

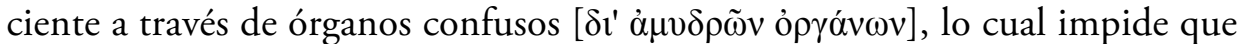
comprenda lo que su alma realmente anhela (cf. 249e-250c). En sí misma, la percepción no es lo suficientemente fuerte como para evocar el recuerdo de la visión prenatal, es decir, por sí sola no permite ver en qué grado los objetos de este mundo participan de las realidades hyperuranias. La visión es la más aguda de las percepciones que proceden a través del cuerpo (cf. 250d3-4), pero ella es incapaz de reconocer en la tierra Ideas como la Justicia o la Sensatez, pues la belleza de éstas no resplandece de manera manifiesta para la visión en los objetos de aquí abajo que de ella participan. La Belleza es la única Idea que tiene el privilegio de resplandecer entre los objetos terrestres que de ella participan (cf. 250d-e). Según se dijo, el ह̌ Así, la forma erótica más genuina es la provocada por las Ideas, que son las entidades más bellas. No obstante, en tanto que la Belleza es la única realidad

\footnotetext{
${ }^{34}$ No en vano, Sócrates describe la visión de las Ideas como un espectáculo de entidades divinas (cf. 250a4).

${ }^{35}$ Esta cuestión no sólo puede apreciarse de forma nítida en el Fedro, sino que en pasajes como Banquete 206a11-12 el propio Platón lo expresa así de modo claro y rotundo.
} 
hyperurania cuyo brillo resplandece entre los objetos mundanos, el alma puede percibir como bellos los objetos terrestres a través del más agudo de los sentidos, a saber, la visión. Cuando el humano ve el resplandor de la Belleza en los objetos sensibles, a causa del olvido cree erróneamente que el origen de su pasión son dichos objetos y no, en cambio, su verdadera fuente, a saber, la Idea de Belleza.

Lo expuesto hasta aquí es suficiente para establecer la distinción crucial que permite comprender en qué consiste la diferencia entre el amor filosófico denominado en este discurso «locura erótica» « $-y$ las restantes formas eróticas. El ह̣̌ $\omega \varsigma$ no filosófico es el que padece un alma que contemplando algo bello no comprende que el verdadero origen de su pasión no reside en ningún objeto mundano, sino en la Belleza en sí, de la cual aquél participa. Por ejemplo, son formas de amor no filosófico el deseo por un cuerpo hermoso o la atracción suscitada por un discurso bello. En cambio, el amor filosófico es aquel que partiendo de la belleza sensible consigue comprender que lo realmente bello no reside en ninguna cuestión terrena, sino en el objeto del auténtico conocimiento. Es decir, el deseo filosófico es amor por la Idea de Belleza y, de manera más amplia, por las Ideas en general ${ }^{37}$. Esto mismo puede apreciarse de manera magistral en el siguiente texto que el Académico pone en boca de Sócrates:

esa locura [la locura erótica] que se produce cuando alguien, contemplan-

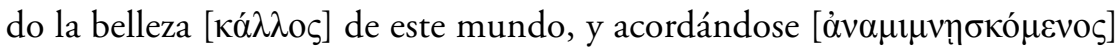
de la verdadera, adquiere alas, y de nuevo con ellas anhela remontar el vuelo hacia lo alto; y al no poder, mirando hacia arriba a la manera de un pájaro, desprecia las cosas de abajo, dando con ello lugar a que le tachen de loco (249d5-e1. Trad. de L. Gil).

El pasaje no sólo es claro, sino que muestra la causa de que un comportamiento tal sea tildado de alocado. Pese a la manera encriptada en la que presenta Sócrates su segundo discurso, según la explicación ofrecida, la pasión erótica no constituye una posesión divina, ni el enamorado es alguien enloquecido ${ }^{38}$.

\footnotetext{
${ }^{36}$ Adviértase que cuando Sócrates recapitula la cuestión de la locura erótica (cf. $249 \mathrm{~d} 6$ ss.), se refiere al amor de tipo filosófico y no a los tipos restantes.

${ }^{37}$ En el fondo, el ế $\omega \varsigma$ es unitario, pues en último término es siempre deseo de conocer las Ideas. No obstante, en función del grado de conocimiento y del recuerdo del alma, dicha pasión se comprende y manifiesta de maneras diversas, que es lo que provoca que algunos lo entiendan como un fenómeno múltiple.

${ }^{38}$ Sócrates presenta así la palinodia para contraponerla a su anterior discurso y por razones que este artículo no entrará a discutir. Para ello, no parte ex nihilo, sino que bebe de una
} 
En realidad, si se reflexiona un poco, se comprende que la anomalía de quien ama de un modo no filosófico no es en absoluto magna. Esta forma de desear es harto conocida en la ciudad y pese a que en ocasiones se explique señalando que se trata de una donación o castigo divino, lo cierto es que resulta habitual. De hecho, todo ciudadano pasa antes o después por un estado de enamoramiento y, por tanto, no constituye algo excesivamente extraño. En cambio, es la manera de desear del filósofo la que causa perplejidad entre sus conciudadanos, pues, lejos de desear nada mundano, vuelve su mirada hacia arriba, descuidando las cosas de aquí abajo. ¿Acaso no es éste el mal que causó la caída de Tales? El amor filosófico consiste en desatender —al menos en primer término- las cuestiones de aquí abajo, por estar primeramente interesado en recordar la auténtica realidad que divisó otrora ${ }^{39}$. Son muy escasas las almas que consiguen recordar lo auténticamente bello a través del reflejo de la belleza en este mundo y, por eso, pese a que la causa primera de todas las formas de amar sea siempre la misma, aparece para la ciudad como extraña e inquietante. Aunque el amor filosófico sea el más natural y apropiado para la naturaleza humana, por ser inusual entre los humanos, se muestra fuera de lugar para los no iniciados. Así, cuando Sócrates describe el amor filosófico como una locura divina, en el fondo, estaría rindiendo cuenta irónicamente de su propia locura, para mostrar que, de hecho, ni se trata realmente de la locura, ni de una anomalía, sino todo lo contrario.

Filosofar, después de todo, fiel a su etimología, no es sino desear la sabiduría, esto es, anhelar conocer las Ideas, que constituyen el auténtico objeto del conocimiento. El filósofo desea por encima de todo conocer, por lo que orienta su atención hacia las Ideas, dejando en un segundo plano el análisis fenomenológico de las entidades de este mundo. Traducido a lenguaje platónico, podríamos decir que filosofar — $\mathrm{O}$ amar el conocimiento - no es otra cosa que practicar continuamente la reminiscencia y la dialéctica ${ }^{40}$. Cuando con notoria sorna Sócrates afirma que para ser un buen orador es necesaria la práctica de la meteorología y

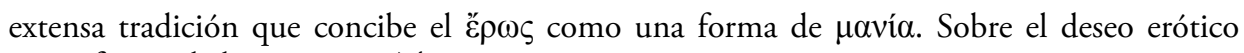
como forma de locura, véase Thornton, 1997, 17.

${ }^{39}$ En cualquier caso, adviértase que en último término el filósofo no descuida el mundo en el que habita, sino que busca el conocimiento de las Ideas, pues sólo así puede alcanzar un criterio fijo para valorar su mundo. Esta cuestión puede apreciarse en la propia explicación sobre

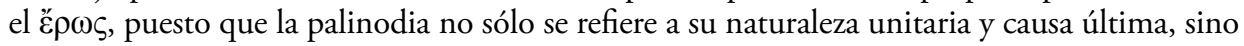
que ofrece además las claves para comprender sus manifestaciones múltiples en la tierra.

${ }^{40}$ Sobre la dialéctica, cf. Fedro 265d3-5, 265e1-3, 266b3-c5. Sobre la reminiscencia, cf. Fedro 249b6-c4. 
de la charlatanería ${ }^{41}$, simplemente, defiende que para dominar el arte retórico es necesario practicar la filosofía (cf. 270a1-4). La filosofía constituye la actitud erótica más natural para el alma, pero a causa de la ignorancia — ligada al olvido de la caída y de la encarnación- de los no versados en ella, es considerada como anómala e, incluso, como alocada. Por eso, de forma irónica Sócrates la define como una locura divina, para mostrar lo ventajoso de dicho extravío.

La tesis que el presente artículo defiende puede contrastarse mediante diferentes pasajes del diálogo. Uno de los más significativos a este respecto es el texto en el que Sócrates señala que aquel que practica la reminiscencia es contemplado por la mayoría como un loco, precisamente, por descuidar las ocupaciones más mundanas, como le pasase a Tales en la anécdota recogida en el Teeteto:

El hombre debe realizar las operaciones del intelecto según lo que se

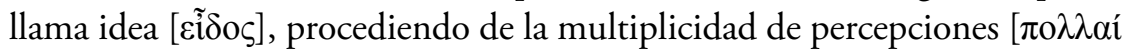

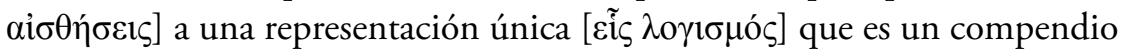
llevado a cabo por el pensamiento. $Y$ esta representación es una reminiscencia [å $\alpha \alpha \mu v \eta \sigma ı \varsigma]$ de aquellas realidades que vio antaño nuestra alma, mientras acompañaba en su camino a la divinidad, miraba desde arriba las cosas que ahora decimos que «son» y levantaba la cabeza para ver lo que «es» en realidad. Por ello precisamente es la mente del filósofo la única que con justicia adquiere alas [ $\pi \tau \varepsilon \rho \circ \tilde{\mu} \mu \alpha 1$, ya que en la medida de sus fuerzas está siempre apegada en su recuerdo [ $\mu v \eta \eta \mu \eta]$ a aquellas realidades, cuya proximidad confiere carácter divino a la divinidad. Y de ahí que el hombre que haga el debido [ỏ $\rho \tilde{\omega} \zeta$ ] uso de tales medios de recuerdo [író $\mu v \eta \mu \alpha]$ sea el único que, por estar siempre iniciándose en misterios perfectos, se haga realmente perfecto. Saliéndose siempre fuera de los humanos afanes y poniéndose en estrecho contacto con lo divino, es este hombre reprendido por el vulgo

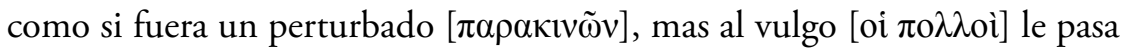

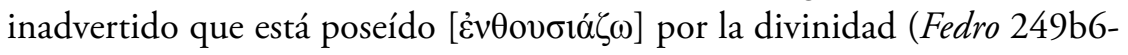
d3. Trad. de L. Gil).

Si bien la ironía es marcada y se juega a caracterizar al filósofo como alguien alado y divino, lo cierto es que expresa con rotunda nitidez que la extrañeza

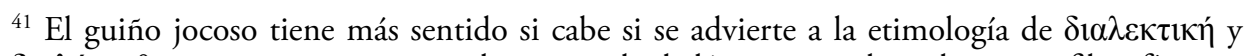
$\delta 1 \alpha \lambda \varepsilon \dot{\varepsilon} \varepsilon \sigma \theta \alpha 1$, que muestran sin ambages que la dialéctica — es decir, la propia filosofía — se realiza a través del lenguaje $[\lambda o ́ \gamma o \varsigma]$. En buena medida, la filosofía se practica a través del diálogo y la discursividad. 
vinculada con el filósofo se debe a la ignorancia de sus conciudadanos, que son incapaces de mantener una actitud erótica adecuada, es decir, de anhelar el conocimiento. Lo que es visto como fuera de lugar, en realidad, según la inversión platónica, constituye la actitud vital más sensata y conforme a la naturaleza del alma ${ }^{42}$. Dicho de otro modo, todos los humanos desean, pero sólo el filósofo lo hace conforme a la naturaleza propia del alma. Es, pues, la ceguera de los demás - y precisamente en esto reside la inversión platónica, a saber, en señalar que lo realmente anómalo no es la actitud del filósofo, sino la de los que no cultivan dicha práctica - lo que provoca que el filósofo sea tomado por loco. Su modus vivendi constituye una anomalía en la ciudad-estado, en efecto, pero no por ser erróneo, sino porque el de sus conciudadanos, a causa de la ignorancia, está desviado. De esta forma, Platón pretende invertir las acusaciones de sus críticos, ofreciendo la razón de que el filósofo sea visto por los demás como alguien extraño ${ }^{43}$ e incómodo, afirmando además que dicha anomalía no constituye un demérito, sino todo lo contrario.

\section{Conclusión}

En sus diálogos, entre otras cuestiones, Platón trata de definir y acotar los límites de su filosofía. Así debe justificar la actitud filosófica y defenderla frente a sus adversarios. La cuestión se reviste de seriedad, pues las sospechas contra la filosofía y los dardos de sus enemigos pueden llegar a cobrarse la vida del filósofo.

\footnotetext{
42 En otros términos, podríamos decir que el amor que siente el alma es originariamente unitario por naturaleza, pero que en función de su grado de conocimiento puede ser captado y manifestado de forma múltiple. Las múltiples maneras en las que se manifiesta el eros constituyen las diversas convenciones que derivan de la opinión que tenemos sobre dicha pasión; no obstante, por naturaleza el eros es unitario y concuerda con el amor filosófico. Así pues, si la

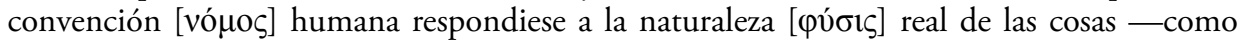
propone el que fuese maestro de Aristóteles-, el amor debería ser siempre amor filosófico y ni parecería anómalo ni se mostraría como idiosincrásico, sino como universal y común entre todos los humanos.

${ }^{43}$ Esta misma cuestión puede verse de forma nítida en otros pasajes del Corpus. Un famoso ejemplo sería el del mito de la caverna, en el que el prisionero que logra salir de la cueva y contemplar la realidad exterior, a su regreso debe proceder con cautela, no fuese que el resto de moradores de la caverna y que no conocen la realidad exterior lo tomasen por loco o, peor aún, como alguien anómalo e incómodo. Esta caución en el regreso resulta imprescindible, puesto que, como atestigua el ejemplo del Sócrates histórico, de expresarse sin tapujos, la ciudad podría tomarlo por un chiflado y, si resultase excesivamente anómalo o incómodo, condenarlo a muerte.
} 
El fundador de la Academia ve con amargura cómo Atenas condena a su maestro a beber cicuta, precisamente, por su actitud filosófica. Se trata, por tanto, de una tarea apremiante. Y no obstante, el Académico sabe enfrentarse a sus adversarios con cierto humor - o mejor dicho, con ironía-. Frente a la comedia aristofáni-

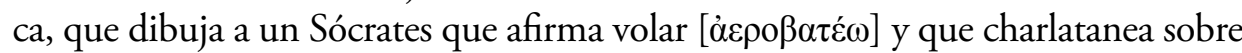
necedades [ $\varphi \lambda v \alpha \rho i ́ a l]$ ajenas a la ciudad (cf. Apología de Sócrates 19c2-5), Platón ofrece unos diálogos que, bebiendo de los recursos de la comedia y la tragedia, deben superarlas sin discusión (cf. Banquete 223d2-7). La razón no es otra que la ya anunciada: para dominar cualquier arte es necesario estar versado en la dialéctica — designada en ocasiones como «meteorología» y "charlatanería»— (cf. 269e4-270a1) y, como, según él, los tragediógrafos y los comediógrafos no son filósofos — de lo contrario, pese a componer poesía trágica o cómica, se designarían a sí mismo «filósofos» y no "poetas»-, no pueden practicar su arte con excelencia. Sólo el filósofo compone representaciones excelsas. Precisamente, los diálogos platónicos, confeccionados con abundantes elementos del teatro clásico, se presentan como la poesía más perfecta ${ }^{44}$. En ella, se emplea la ironía y la sorna, así como otros recursos del teatro clásico, pero para transmitir una enseńanza seria. Lo que se plantea, en el fondo, es que para realizar los quehaceres propios de la ciudad de la manera más sensata, es necesario practicar la filosofía.

Con notable ironía Platón recoge en sus diálogos los dardos lanzados contra la filosofía y trata de darles la vuelta mediante una inversión típicamente cómica. Se emplea un recurso del teatro cómico, por tanto, pero para expresar un asunto máximamente serio, a saber, salvar el buen nombre de su maestro y, lo que es más importante, la propia filosofía. Los diálogos ponen en juego infinidad de cuestiones $y$, en ocasiones, de forma más o menos cómica. No obstante - y esto es lo más relevante-, tras ellos siempre subyacen problemas de máxima gravedad, a saber, la enseñanza y transmisión de la propia dialéctica (cf. 265c8-d1), que, según este texto defiende, es equivalente a la propia filosofía. Después de todo, la mejor manera de honrar a su maestro es dar continuidad a su propuesta, es decir, defender, acotar con precisión y afianzar la filosofía. De la ironía y la inversión, por tanto, debe aflorar la cuestión más seria: salvar la filosofía.

\footnotetext{
44 Téngase presente que la filosofía compite por la hegemonía didáctica, entre otros, con los poetas.
} 


\section{Bibliografía}

Bonazzi, Mauro (2010). I Sofisti. Roma: Carocci.

- (ed.) (2011). Platone. Fedro (trad. y ed. de M. Bonazzi). Torino: Giulio Einaudi editore.

Boyancé, Pierre (1946). "Les Muses et l'harmonie des sphères”. En: Mélanges dédiés à la mémoire de Felix Grat. Vol. I. Paris: Pequeur-Grat.

Brisson, Luc (ed.) (2004). Platon, Phèdre (trad., introducción y notas de L. Brisson). Paris: Flammarion.

Cassin, Barbara (1995). L'effet sophistique. Paris: Éditions Gallimard.

Cooper, John M. (1985). "The Independence of Oratory from Philosophy”. Proceedings of the Boston Area Colloquium in Ancient Philosophy I, pp. 77-96.

Dover, Kenneth J. (1978). Greek Homosexuality. Cambridge: Harvard University Press.

Ferrari, Giovanni R. F. (1987). Listening to the Cicadas. Cambridge: Cambridge University Press.

Hadot, Pierre (2008). Elogio de Sócrates (trad. de A. Millán). Barcelona: Paidós.

Kerényi, Karl (2004). Eleusis. Imagen arquetípica de la madre y la hija (trad. de M. Tabuyo \& A. López). Madrid: Siruela.

Martinelli Tempesta, Stefano (2003). "Sul significato di $\delta \varepsilon v ́ \tau \varepsilon \rho o \varsigma \pi \lambda o \tilde{v} \varsigma$ nel Fedone di Platone”. En Bonazzi, M \& Trabattoni, F. (eds.). Platone e la tradizione platonica. Milano: Cisalpino.

Nails, Debra (2002). The people of Plato: a prosography of Plato and other Socratics. Indianapolis: Hackett Publishing Company.

Nightingale, Andrea Wilson (1995). Genres in Dialogue: Plato and the Construct of Philosophy. Cambridge: Cambridge University Press.

Rowe, Christopher. J. (ed.) (1988). Plato. Phaedrus (trad. y comentario de Ch. J. Rowe). $2^{a}$ edición. Warminser: Aris \& Phillips.

Sala, Eva (2007). Il Fedro di Platone. Commento (Tesis doctoral). Padova: Università Degli Studi di Padova.

Solana Dueso, José (2013). Más allá de la ciudad. El pensamiento político de Sócrates Zaragoza: Institución Fernando el Católico.

Thornton, Bruce S. (1997). Eros: the myth of ancient Greek sexuality. Boulder: Westview Press. 
Tordesillas, A. (2013). "Discours rhétoriques et conduite des âmes: dialectique, psychagogie, politique dans le «Phèdre» de Platon". En: M. J. de Carvalho \& A. Caeiro \& H. Telo (eds.). In the Mirror of the Phaedrus. Sankt Augustin: Academia Verlag.

Trabattoni, Franco (ed.) (1995). Platone. Fedro (trad. de L. Untersteiner Candia; ed. de F. Trabattoni). Milano: Mondadori.

- (2001). "L'argomentazione platonica”, Problemata Vol. 1, pp. 7-38.

- (2012). "Myth and Truth in Plato's Phaedrus". En: Collobert, C. \& Destrée, P. \& Gonzalez F. J. (eds.), Plato and Myth, Leiden: Brill.

Velardi, Roberto (ed.) (2006). Platone. Fedro (trad., introducción y notas de R. Velardi). Milano: BUR.

de Vries, Gerrit Jacob (1969). A commentary on the Phaedrus of Plato, Amsterdam: Hakkert.

Wasson, R. Gordon \& Hofmann, Albert \& Ruck, Carl A. P. (1978). El camino a Eleusis: una solución al enigma de los misterios (trad. de F. Garrido). México: Fondo de Cultura Económica.

Werner, Daniel S. (2012). Myth and Philosophy in Plato's Phaedrus. Nueva York: Cambridge.

Enviado: $17 / 08 / 2016$

Aceptado: 30/01/2017

Este trabajo se encuentra bajo una licencia de Creative Commons ReconocimientoNoComercial-SinObraDerivada 4.0

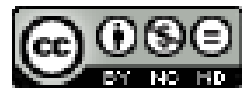


